\title{
INTELLECTUAL PROPERTY AND THE MARKETS OF IDEAS
}

\author{
Giovanni B. Ramello
}

\section{Introduction}

The term intellectual property rights denotes a set of legal doctrines -namely patent, copyright, trademark and trade secret- that differ in their structure, scope and spheres of application, but nevertheless have in common the feature of granting the owner rights over the economic exploitation of an idea or its 'reification' (i.e. its expression in any tangible medium, as in the case of copyright-author's right). Such rights are generally exclusive, meaning that the owner is given a legal monopoly over the protected idea ${ }^{1}$.

From this perspective, therefore, and despite the distinct peculiarities of each, the roots of all intellectual property rights can be traced to the advent of a knowledge economy and the private appropriation of certain types of information. In fact, as the production of knowledge began generating increasing value, in tangible economic terms as well as socially, the question arose as to the appropriability of this new knowledge - or more to the point of the benefits derived therefrom-, which was resolved in Western commercial and industrial societies through the attribution of specific property rights. In this respect, intellectual property rights are only one possible solution to the dilemma of the ownership of knowledge ${ }^{2}$.

Different societies have naturally resolved this dilemma in different ways ${ }^{3}$. Of the various possible solutions, that adopted by Western society is especially propitious to the circulation of knowledge within economic contexts and its exploitation on the marketplace ${ }^{4}$. Moreover, it has the effect of specifically stimulating the production of those ideas that the market most readily rewards. Hence, the traditional benefit associated with intellectual property rights, at least from the law and economics perspective, is that it provides an incentive for the creation and/or dissemination of new ideas. But intellectual property rights have yet another feature in common, one that is often neglected in the literature, but central to the economic analysis: namely that, by the very fact of being property rights, they contribute by definition to shaping the market 
structure, regulating the competitive scenario and determining the rational behaviours of economic agents.

In other words, property rights are not merely static instruments for fine tuning the market of ideas; they are much more pervasive in their effects, able to shape the features of markets and bring about the emergence of particular actors, with a sometimes significant impact on creative and inventive processes, as well as on innovation. In the present discussion we shall give equal weight to both perspectives, starting from the traditional analysis and its sources, and then addressing the indirect economic effects on the configuration of the markets. More specifically, section 2 will describe the origins of the economic interpretation of intellectual property, presenting the traditional 'static' paradigm. Section 3 will discuss the application of this paradigm to the various specific rights, illustrating their peculiar features. Section 4 will go on to discuss the 'dynamic' role of intellectual property rights, showing how these institutions play a decisive role in shaping the markets of ideas. Finally, section 5 proposes some directions for future development that are currently being explored, albeit fragmentarily, by the contemporary scientific debate.

\section{Origins of intellectual property}

The economic interpretation of intellectual property rights is a direct descendant of the theory of labour-mixing and property formulated by John Locke (1632-1704). This theory is in fact the cornerstone of the reasoning that establishes a causal link between creators and ideas, thereby legitimising the individual appropriation of the latter through the ad hoc institution of property rights.

In his second book of the Two Treatises on Government (1690), Locke maintains that every man has a 'natural right' to appropriate the fruits of the labour of his own body. In other words, the English philosopher believed that individuals acquire property rights over assets originally contained in the state of nature, by virtue of the fact that in order to extract them they contribute their own labour, and hence a part of themselves (Drahos, 1996).

Locke did not however espouse this position absolutely, but considered it subject to some clear-cut and essential derogation criteria. He in fact defined specific limits for appropriation, in the form of two provisos that appear to foreshadow the Pareto optimality criterion: i.e. that an individual can extract from the state of nature only that which leaves "enough and as good left for others", and in any case that "the same law of nature, that does by this means give us property, does also bound that property too [...] Nothing was made by God for man to spoil or destroy” (Locke, 1690, sect. 27). 
Locke thus implicitly asserted for the first time that there exists a trade-off between private appropriation and the public sphere, an idea taken up by all the subsequent literature on intellectual property, which has sought in various ways to preserve and enrich the shared resource in question - the 'common' and later the 'creative common' as defined in some of the literature (Hardin, 1968; Lessig, 2001)- whilst at the same time guaranteeing a sufficient private incentive through individual appropriation. In any case, the two Lockean provisos provide a simple but effective rule of reason for regulating the extension of such rights, and for resolving any conflicts between private and public interest that might arise. The various criteria for derogation from intellectual property rights -temporal limit, right exhaustion in EU jurisprudence or first sale doctrine in US law, fair use doctrine in the case of copyright, minimum threshold for attribution, etc.- can thus be viewed as descendants of the Lockean prescriptions, whose ultimate aim is to minimise the negative effects of private appropriation and favour the return of new knowledge to the public sphere.

Nevertheless, economic analysis proper, as an independent discipline, only entered into the intellectual property rights debate later, with Adam Smith (1723-1790) ${ }^{5}$, who questioned the natural right of individuals over created ideas, whilst upholding the importance of (limited) exlege protection "as an encouragement to the labours of learned men".

Smith's position is only blandly in favour intellectual property, probably reflecting a disinclination to uphold any type of monopoly -even a legal one- that interferes with competitive process. He thus admits lukewarm support for intellectual property rights "as they can do no harm and may do some good, are not to be altogether condemned" (Smith 1762, Lectures on Jurisprudence, in Goldstein, 1994, p.173), but ultimately, no clear theoretical or policy indications emerge.

The challenge of developing a more robust paradigm was picked up by Jeremy Bentham (1748-1832), who provided the theoretical groundwork for centuries to come by first formulating the utilitarian theory of an 'incentive to create', widely adopted by the ensuing literature up until the present day. In particular, the English economist notes that "he who has no hope that he shall reap, will not take trouble to sow" (Bentham, 1839, p.31). In fact Bentham (1839, pg. 71) observes: "that which one man has invented, all the world can imitate. Without the assistance of the laws, the inventor would almost always be driven out of the market by his rival, who finding himself, without any expense, in possession of a discovery which has cost the inventor much time and expense, would be able to deprive him of all his deserved advantages, by selling at a lower price” (Bentham, 1839, pg. 71). Intellectual property can therefore offer a practicable solution to this problem. 
Note that Bentham's assertion in a sense prefigures the dilemma of the appropriability of public goods, and poses an implicit challenge to the Smith model of perfect competition: the invisible hand alone is not able to govern markets of ideas which, without specific intervention by the legislator, will be therefore doomed to failure ${ }^{6}$.

A strong awareness of the problem of free-riding and its negative effects on the remuneration of creators prompted Bentham to openly side with an institution that provides an incentive for creative activities. The creator, he asserts, must be protected against opportunistic individuals who would otherwise "without any expense, in possession of a discovery which has cost the inventor much time and expense, be able to deprive him of all his deserved advantages, by selling at a lower price” (Bentham, 1839, pg. 71).

Now, the above cited theory has played a 'totemic' role in the law and economics literature on intellectual property, providing a universal reference framework for nearly all subsequent contributions, which have incrementally fine-tuned the analysis, systematised and updated it, occasionally levelled some criticisms, but always held the central paradigm intact ${ }^{7}$. We can in other words draw a direct line of continuity between the model proposed by Bentham and the literature of law and economics. In like manner we can argue that the contribution of 20th century economic theory has essentially been to extend and reinforce the Benthamian paradigm, by providing further arguments in support of the general incentive-creating role of intellectual property rights.

In effect, we have on one side an entire branch of literature grown out of Schumpeter's (1943) contribution, which posits the centrality of innovative activities to economic systems and their growth, and implicitly attributes to intellectual property rights a determining role in this dynamic $^{8}$. And on the opposing side we have the theory of intellectual property rights as an efficient solution to the problem of public goods and externalities, which has provided the standard argument for the specific case of intellectual property, upholding the pro-efficiency role of intellectual property rights (Coase, 1970$)^{9}$.

\section{Intellectual property rights and incentives}

Although there are only four types of intellectual property right, in practice there exist as many variants as there are nations that recognise them ${ }^{10}$. Some of the distinctions are minor, while others reflect differences in the underlying regulatory frameworks. This is true, for example, in the case of copyright in common law systems and author's rights in civil law systems, where the different designations indicate, at least in theory, a different conception of the role of the author. In practice, however, recent convergence of international regulations has 
eroded these distinctions, to the point that some observers claim that, notwithstanding the differences, the two institutions have evolved through a dialectical process and thus exhibit common traits (Strowel, 1993).

Further diminishing the diversity are the effects of regulatory dynamics impressed at an international level by the TRIPS agreement (the Agreement on Trade-Related Aspects of Intellectual Property Rights), defined and ratified by the World Trade Organisation (1994), and which essentially seeks to bring about a gradual international unification of the doctrine for enforcement of intellectual property rights ${ }^{11}$.

The various types of intellectual property rights are instead differentiated according to the type of information that is protected (the so-called subject matter), the attribution criteria, the type of exclusive right granted to the owner (in terms of its structure and duration) and the incentive conferred ${ }^{12}$.

Patents generally protect ideas relating to the technological and scientific spheres (i.e. new products or novel production processes) and grant the inventor/discoverer -or his employer- an exclusive right of limited duration (which varies from country to country) as a reward for shouldering the risk and investments connected with the research and development of the new idea $^{13}$.

Transferring original ownership of the patent from the inventor to his employer -who becomes for all intents and purposes the inventor- should not, at least in theory, undermine the incentive mechanism, because it fulfils the criterion of risk transfer: the company agrees to take on the risk, and is thus entitled to benefit from the success of the venture, while the inventor receives a guaranteed remuneration in return. Now, in a market characterised by perfect information, in which there are no financial or other types of imperfections, such a mechanism will effectively be able to efficiently allocate the risk and stimulate inventive activities at the same time. Otherwise, if the above-listed conditions are not met, the outcome will not be as expected and the goal of efficiency will not be achieved (see Scotchmer, 1991 and 1998).

Because a patent application procedure requires revealing the invention, the institution of patents also creates an incentive to disclose new information. This twofold character of the resultant incentive -to create and to disclose- does not, however, have strong implications for the economic analysis, because in this case undisclosed information will not permit exploitation of a legal monopoly, and hence provides no incentive to create. In consequence, any profits deriving from exploitation of the exclusive right necessarily entail disclosure of the patented idea, and hence an equivalence between the two incentives.

The granting of a patent is not automatic, but subject to fulfilment of three criteria: the criterion of novelty, which calls for a substantial advance with respect to preceding inventions, 
the criterion of non-obviousness, which requires that the advance should not be trivial and, finally, the criterion of utility, which requires the invention to have some application and therefore not to be an end in itself. Complying with these criteria should ensure that strong exclusive rights are granted only to those ideas that effectively constitute a real technical or scientific advance.

Copyright-author's rights, on the other hand, protect expressions of ideas, i.e. information fixed in any tangible medium such as books, CDs, films, software and the like ${ }^{14}$. They are granted based on a criterion of minimal originality, meaning that the new expressions of ideas need only be marginally different from pre-existing ones ${ }^{15}$. In reality, there is no verification procedure involved in the granting of copyright, and if anything it is plagiarised authors who must contest the damage caused by some other, insufficiently original, expression of idea.

Moreover, because fixing of a copyright-protected idea in a tangible medium is in a sense instrumental to the consumption of individual units, while the information contained therein remains fluid and easily duplicated, copyright includes provision for a bundle of rights that also regulate its reproduction and dissemination ${ }^{16}$. We can therefore say that if technology somehow makes it possible to package information (Thomas Edison eloquently dubbed the phonograph, his invention for recording and playing back sound, 'canned sound ${ }^{, 17}$ ), converting it into private unit goods that can be exchanged on the market like traditional goods, copyright provides the legal glue for 'sealing the can' created by technology, and preventing undue appropriation.

Copyright is thus an exclusive right, granted to the author as an incentive to create, in agreement with the premises of the Benthamian paradigm. It should in theory have limited duration, to permit the subsequent enrichment of public knowledge. In practice, though, following various amendments considerably strengthening the right (with the US Copyright Term Extension Act 1998 it can last up to 70 years post mortem autoris, or 95 years in the case of a company owning the right, while the European Duration Directive 93/98/EEC has extended protection to 70 years post mortem autoris) its duration has become virtually infinite, at least for the purposes of economic analysis ${ }^{18}$. It is this last mentioned aspect that raises some serious questions concerning the global efficiency of the right (Antill and Coles, 1996, Lessig, 2001).

The incentive of copyright stimulates the creation of new expressions of ideas, by guaranteeing to the owner, who is generally the author (in the US case of work made for hire, as in the case of patents, the company that takes it on can be considered to be the author), exclusive rights over the economic exploitation of the intellectual property in all its forms, both direct and indirect.

Trade secret similarly seeks to stimulate the creativity of individuals by guaranteeing rights of secrecy to those who produce certain forms of information, generally pertaining to production 
processes (e.g. the formula for a particular soft drink, a customer list, etc.) ${ }^{19}$. In fact such information, once disclosed, can be easily appropriated and imitated by competitors, thereby reducing the incentive for the creator to invest resources in its development, if he will be unable to later profit from it.

Some authors do not concur in assigning to trade secret the attributes of property, for the reason that trade secret is not necessarily exclusive, with nothing preventing several individuals from unwittingly owning the same secret ${ }^{20}$. For the purposes of this discussion, though, this observation can be set aside because trade secret is still based on the same rationale as all other intellectual property rights: granting a private benefit to the owner of a given information good, in order to create an incentive for its production. The fact that such a right may (unwittingly) be shared by two or more individuals does not compromise the logic of the system, and constitutes at worst an imperfection ${ }^{21}$. In any case, the economic behaviours of the owners are decided independently, irrespective of the possible existence of co-owners, and hence as if they effectively had exclusive rights over that particular information.

Trade secret has the function of conferring a competitive advantage to the owner in exchange for the creation of new information. Hence, the prospective existence of two or more co-owners will in the worst case cancel out the advantage, with some interesting pro-competitive side effects, for example by fostering price competition. The only downside to this eventuality is that two separate individuals are given an incentive to invent the same information, with the attendant duplication of expense. Still, this actually happens much more often in the realm of patents, where the problem is solved by a questionable ex-post attribution that does not avoid the ex-ante allocation inefficiency ${ }^{22}$. It should nevertheless be emphasised that such situations are the exception, and not the rule.

The overall balance of welfare resulting from trade secret is somewhat more uncertain than for other intellectual property rights, because the right can endure up to the time when, for whatever reason, the information is disclosed and enters the public domain. This means that, at least in principle, it can last for an unlimited period. If the protection is effectively prolonged indefinitely, the social benefits will be very slight, because the protected information remains forever private. To a degree, trade secret does provide a certain incentive to develop new and improved products; however, the fact of non-disclosure prevents appropriability of the knowledge for incremental creation -a fundamental point because the owners of the right may not necessarily be the most efficient creators for subsequent developments. On the opposing side, it does give a competitive advantage to the owner of the right, who could exploit the position thus obtained to pursue rent-seeking behaviours detrimental to general efficiency and welfare. 
Finally, on top of the social costs arising from exercise of the right, we must also factor into the welfare balance the costs incurred in keeping the information secret. But these costs are also the key to solving the dilemma of duration: precisely because secrets are difficult and expensive to keep, it can generally be expected that the information will sooner or later be publicly disclosed (Friedman, Landes and Posner, 1991).

Trademark, finally, is an exclusive right that likewise seeks to foster the creation of new information. However the information in question is, at least in the first instance, only an accessory to goods of other markets. Trademark generally serves to convey information about the quality of products and the reputation of manufacturers, for the benefit of consumers (Landes and Posner, 1987).

However some authors have recently put forward the thesis that trademark creation might be an economic end in its own right, serving to confer on the owner reputation inertia--and therefore market power--that is extensible and transferable to other markets, as in the case of 'brand extension and brand stretching' (Choi, 1998; Pepall and Richards, 2002), and that a trademark might even constitute an independent asset (Tadelis, 1999) or a well-defined symbolic good for which consumers exhibit a specific willingness-to-pay.

By carrying a certain amount of information about a product, a trademark effectively enables a product to be differentiated from its competitors, and ultimately gives the owner some degree of market power, which increases in direct proportion with the impact that the brand itself has on consumers ${ }^{23}$. So trademark has the additional, secondary effect of altering the quality perceived by consumers, who may consider equivalent products to be different solely because they are marketed under different brand names. This naturally has the effect of altering their willingness to pay and hence the balance of welfare.

From the attribution standpoint, because the public goal of trademarks is to facilitate exchanges by giving consumers more information about the goods that they are purchasing, trademark law does not generally admit appropriation of words or symbols denoting specific categories of objects (e.g. a car maker will not allowed to use the term 'car' as a trademark, whereas a manufacturer of garments and fashion accessories can use the word 'diesel'). Accordingly, continued protection is denied to trademarks which, for a variety of reasons, have entered into the common language and come to denote generic product categories (as in the celebrated cases of frigidaire, typewriter, elevator, aspirin, nylon, kerosene, yo-yo, etc., all originally brand names). 


\section{Intellectual property rights and markets}

Generally speaking, law and economics theory treats all the above-mentioned rights as being neutral in their effects on the markets of ideas: given the economic context, the rights have the sole function of favouring an efficient equilibrium, without significantly altering the nature of the markets. However this assumption is by definition incorrect: given that intellectual property rights embody specific economic policy measures -namely an effort to encourage an efficient level of ideas- they are instruments of market regulation and therefore influence the competitive configuration, altering it not just marginally, but drastically (Ramello, 2003a). This is a dynamic that has been by and large neglected by the scientific literature. In fact the model implicitly adopted by much of the economic theory on intellectual property rights is more of a Schumpeterian innovation race, adapted to fit the various creative contexts, which takes the form of a type of perfect intertemporal competition (Evans and Schmalensee, 2001). In other words, according to a large part of the literature, the prospect of enjoying temporary supraprofits -brought by the exclusive rights- gives creators an incentive to put new ideas on the market, which does however remain competitive over the long term (see for example Besen and Raskind, 1991).

This representation has long been associated with a related view, namely that market success coincides with optimality of ideas, i.e. that the market always causes the best ideas to emerge, so that the above-described mechanism is efficient from every perspective. But this idea, too, has been discredited by the literature of the past decade, which points out how the short run profit-maximisation goals of firms and the uncertainty of creative activities are fundamentally at odds with the long-run welfare maximisation goal, thereby penalising and crowding out certain types of creative activities such as, for example, basic research (Dasgupta and David, 1994; Arora and Gambardella, 1997; Scotchmer, 1998).

Nonetheless, the mainstream approach continues to rely on the assumption that the legal framework does not stifle -but on the contrary enhances- the competitiveness of the market ${ }^{24}$, neglecting to note that the specific incentive mechanisms have the effect of significantly altering the payoffs and the maximising behaviours of economic agents. Such effect emerges clearly from surveys on specific industries, which indicate that the market structure of the investigated sectors is significantly altered with respect to both the competitive and Schumpeterian structure $^{25}$.

Having said that, the primary aim of intellectual property rights is, by definition, to give the owner a certain amount of market power, and this has clear-cut effects on the competitive structure. This is a key point for the economic analysis, and must be properly understood. In 
effect, there is a widely held belief that the legal monopoly conferred by exclusive rights does not necessarily confer market power on the owner, or translate into an economic monopoly (see Anderson, 1998). Now, this is an acceptable assertion in general terms, but subject to misinterpretation ${ }^{26}$. It is effectively true that intellectual property right-protected information, if not successful, will not allow the legal monopoly to translate into an economic monopoly: a trademark that means nothing to consumers will not differentiate a product from its competitors. A drug that is ineffective, even it is patented, will not confer any kind of market power. A CD that nobody is interested in buying can by no means be considered an economic monopoly, even though its copyright protection does make it a legal monopoly. Ultimately, the legal monopoly will translate into an economic monopoly only when consumers perceive the information good protected by intellectual property right as being poorly substitutable for other information $\operatorname{goods}^{27}$. Only then does exclusive control over the non-substitutable resource confer market power to the owner, in inverse proportion to the substitutability of the good.

In some cases, when this market power is at a maximum, the legal monopoly becomes an economic monopoly; in other cases this is only partially achieved, but still allows the owner of the right to enjoy a certain profit margin. In any case, it is the prospect of securing supraprofits (and therefore market power) that constitutes the incentive to create, since a perfectly competitive market would deliver no extra profits and therefore zero incentive. The logic behind intellectual property rights is thus to reward successful ideas with market power: providing a monopoly, to a greater or lesser extent, as a private benefit in exchange for the creative effort/investment.

In the above section we have discussed how trademark increases the amount of information associated with a given product, thereby benefiting consumers, but that in so doing it also serves to differentiate the product from competing ones, i.e. attributes market power, thereby benefiting the company that owns the right. A similar dynamic can be observed in other markets where the reward mechanism likewise hinges on the erection of de jure entry barriers that effectively confer market power.

Summarising the above arguments, therefore: a systematically competitive scenario implies a high level of substitutability between products; in this scenario, though, a complex apparatus such as intellectual property rights is not economically efficient, because it would be enough to directly finance the production of just a few ideas (as they are perfectly interchangeable) thereby sidestepping the social costs of intellectual property and the duplication of expense incurred in the production of equivalent ideas ${ }^{28}$.

Now, according to the economic rationality hypothesis it can be reasonably expected that those in possession of market power will not stop at its temporary enjoyment but, as rational 
actors, strive to maintain it over time. This is borne out by the comparison of intellectual property industries affected by pockets of monopoly (Shapiro, 2000).

Then the result is an intractable economic dilemma, which has thus far received very little attention: on the one hand, intellectual property rights can have the beneficial effect of stimulating the production of new ideas and competition, through the promise of temporary supraprofits; but on the other hand, because they introduce a monopolistic slant to the markets to a greater or lesser extent depending on the conditions- they also foster the emergence of rentseeking behaviours which gradually skew the competitive scenario, degrading its overall efficiency. To date, this drift has only been acknowledged in a few sporadic cases, where it was found that intellectual property rights can sometimes be manipulated for anticompetitive purposes.

The first precedent-setting case was probably US vs. United Shoe Machinery ${ }^{29}$ in the United States, where both the antitrust authority and academics determined that an accumulation of intellectual property rights, albeit in respect of the law, could be used to restrict competition (Anderson, 1998) ${ }^{30}$. Since then, similar cases have been described in the scientific and legal literature, without however leading to a definitive and comprehensive theoretical paradigm. Some examples are the 'brand proliferation' strategy described by Schmalensee (1978), in which the ownership -and exploitation- of multiple trademarks within a given product category in reality conceals a strategy of foreclosing the market to potential competitors. In like manner, it has been shown that ownership of a large number of unexploited patents -commonly termed 'sleeping patents'- has the real purpose of restricting the scope of competition open to newcomers (Gilbert and Newbery, 1982). By the same token, an incumbent might work around a principal patent -a practice known as 'inventing around'- with the sole purpose of producing sleeping patents and thereby locking out the competition.

Many sectors that produce intellectual property-protected goods are characterised, even today, by strategies such as these, which are open to conflicting interpretations. Now, the accumulation of rights and the joint ownership of rights can be viewed not just as the signs of a market-foreclosure strategy, but also as practices aimed at minimising risk -and which are therefore genuinely competitive- in markets characterised by great uncertainty (Ramello, 2003a).

This ambiguity of interpretation crops up frequently in the literature and in practical cases, as a consequence of the fact that intellectual property is $a b$ origine a monopoly space (albeit only potentially, and not always in practice) granted to creators as a reward for their activity. Hence, the anticompetitive behaviours of owners are to some degree consistent with the legal incentives provided to them, that is to say rational and competitive within the altered economic framework. 
Recent European and US legislation has repeatedly brought to light the tensions that exist on this matter. The European NDC Health/IMS Health ${ }^{31}$ case, for example, clearly showed how exploitation of the legal monopoly granted by the right treads a fine line between legitimacy (under the intellectual property right laws) and illegitimacy (under the antitrust regulations). But even in the controversial US Microsoft case, where an abundance of disparate elements revealed a well-developed anticompetitive strategy, intellectual property rights were invoked to support the legitimacy of these behaviours ${ }^{32}$.

In general, therefore, the existence of market imperfections (Williamson, 1977), of complex economic strategies relating -for example- to interconnected markets and/or multiproduct firms (see De Vany and Walls, 1999 for the extended video sector), of rent-seeking inertia arising from pockets of monopoly power, all have the combined effect of gradually altering the structure of the competitive scenario, causing it to drift away from the Schumpterian model, progressively eroding the competitiveness and efficiency of the markets.

This dynamic effect therefore alters the overall balance of welfare, and so must be taken into account in the economic analysis of intellectual property.

\section{Recent developments}

The contributions discussed thus far are all, in any case, referred to a scenario that could be described as obsolete from the technological, scientific and economic standpoints. Recent innovations have in fact already extensively called into question a regulatory system that is anchored to an out-of-date technological substrate, ignoring the effective rapid evolution and mutations of the technology landscape.

The lively contemporary debate, covered extensively in the media, reveals widely diverging views as to the function and effectiveness of intellectual property rights in the various current and future socio-economic contexts. At the root of this disagreement are two specific, and in a sense opposing, phenomena. On the one hand, technological change has de facto weakened the right, by providing new tools for the duplication and dissemination of information, thereby endangering the consolidated interests of intellectual property stakeholders. This is what happened, for example, in the celebrated Napster $^{33}$ case, where it was not just the violation of copyright that was put on trial, but the new peer-to-peer file sharing systems themselves ${ }^{34}$. So the advent of new behaviours made possible by novel technologies, coupled with reliance on traditional legal paradigms that no longer fully fit the altered context, poses a thorny dilemma that can only be solved by looking beyond vested interests. Without a doubt, blindly coming down on the side of intellectual property is not an optimal solution, because there is just as 
strong a need to preserve the innovative dynamic which, even if it compromises pre-existing interests as a side effect, does not for this reason lose importance (Lessig, 2001) ${ }^{35}$. This idea finds solid support in the very same literature on innovation, pioneered by Schumpeter (1943), which in its time upheld the importance of intellectual property. Some recent authors have in fact gone back to this work as a starting point to rediscover Arrow's solution (1962) of an upstream remuneration system that does not disturb the competitive nature of the downstream market (Boldrin and Levine, 2002).

On the other hand, the scientific and technological dynamic itself creates new opportunities for profit under the existing regulatory framework, thereby stimulating behaviours that have little to do with innovative investment, but are aimed instead at securing new sources income, if necessary by diverting resources away from other creative and productive activities (David, 2000). This state of affairs has been judged to exist, for example, in the case of the patenting of genetic material, where the current system is often manipulated for purely rent-seeking aims, with the not-inconsiderable side effect of damaging scientific activity which is of necessity incremental, and relies upon appropriation of preceding knowledge (Barton, 2000; Bobrow and Thomas, 2001) ${ }^{36}$. This threat is propagating across the entire sphere of open science and technology, which are increasingly encroached upon by the indiscriminate extension of proprietary systems and the resultant progressive erosion of the public domain, that is so necessary and essential for creative activities (David, 2000).

Generally speaking, today we are witnessing an unprecedented extension of traditional rights into new spheres, in a manner not always clearly justifiable by the logic of incentive. Some cases worth citing, among those currently being debated, are the patentability of business concepts (Merges, 1999) and software.

This relentless expansion of the current legal apparatus is generating a highly fragmented and complex system of rights, whose management incurs high transaction costs, with the effect of discouraging those types of creative activities that cannot afford these new costs. In other words, the markets of ideas -though rescued from the risk of failure due to free-riding- are now in danger of another type of failure arising from the proliferation of rights and the attendant heavy operating costs. This eventuality has been described in the literature as the 'tragedy of the anticommons' (Heller, 1998).

Finally, a number of quite recent contributions, driven also by the unprecedented creative dynamics of the Open Source software movement, which has even generated its own body of literature (see Lerner and Tirole, 2001; vol. 32, issue 7 of Research Policy, 2003), consider the possibility of formulating incentive paradigms for creative activities that are either alternative or complementary to intellectual property, and able to contain the costs of an overly burdensome 
legal system. In particular, these authors strive to better understand the processes involved in creativity and knowledge-production by referring to specific studies from the other human sciences, invoking the 'gift' paradigm used in anthropology to at least partially explain the creative dynamic (Gordon, 2002 ; Gordon, 2003 ; Zeitlyn, 2003), or the shared character of social processes that constitute the environment in which knowledge is produced (Benkler, 2002; Ramello, 2003b).

\section{Conclusive remarks}

This contribution attempts to systematise the law and economics theory as it relates to intellectual property rights, while at the same time suggesting new perspectives for analysis. In fact, as is discussed in sections 2 and 3, the standard literature relies essentially on the thesis of an incentive to create and/or disclose new ideas. However, although this argument doubtless remains valid in the general case, it fails to satisfactorily take into account various consequences arising from the new legal institutions and the specific technological context. One important such consequence is the dynamic effect of intellectual property rights on the market structure of the sectors involved, which can at times interfere with the original competitive processes, or even drastically alter them.

An economic analysis based on these premises --though as yet fragmented and non systematic-- might reveal a different overall balance of welfare for the individual rights and therefore lead to different regulatory and policy indications. In particular, it would appear necessary to consider the peculiar social and productive attributes of the various markets of ideas, which require an ad hoc analysis, whereas reliance on a universal theory seems increasingly inadequate and conducive to inefficient economic results. 


\section{References}

Alford W. P. (1995), To Steal a Book is an Elegant Offense. Intellectual Property Law in Chinese Civilization, Stanfortd University Press, Stanford.

Antill J. e Coles P. (1996), 'Copyright Duration: The European Community Adopts 'Threee Score Years and Ten’, European Intellectual Property Review, 18, 379-383.

Anderman S. (2000), EC Competition Law and Intellectual Property Rights, Oxford University Press.

Anderson R. D. (1998), 'The Interface between Competition Policy and Intellectual Property in the Context of the International Trading System', Journal of Internatonal EconomicLaw, 1, 655-678.

Armstrong M. (1999), 'Competition in the Pay-Tv Market', Journal of Japanese and International Economies, 13, 257-280.

Arora A. and Gambardella A. (1997), 'Public Policy Towards Science: Picking Stars or Spreading the Wealth ?', Revue d'économie industrielle, 79, 63-75.

Arrow K.J. (1962), 'Economic Welfare and the Allocation of Resources for Invention, in Nelson R.R.(ed.), The Rate and Direction of Inventive Activity, Princeton University Press, Princeton.

Barton J.H. (2000), 'Reforming the Patent System’, Science, 287, 1933-1934.

Benkler Y. (2003), 'Coase’s Penguin, or, Linux and The Nature of the Firm', Yale Law Journal, 112, 369-446.

Bently L. and Sherman B. (2001), Intellectual Property Law, Oxford University Press.

Besen S.M. (1998), 'Intellectual Property', in Newman P. (ed.), The New Palgrave Dictionary of Economics and the Law, Macmillan, London.

Besen, S.M. and L.J. Raskind (1991), 'An Introduction of the Law and Economics of Intellectual Property', Journal of Economic Perspectives, 5, 3-27.

Blakeney M. (1998), 'Communal Intellectual Property Rights of Indigenous Peoples in Cultural Expressions', The Journal of World Intellectual Property, 1, 985-1002.

Bobrow M. and Thomas S. (2001), 'Patents in a Genetic Age', Nature, 409, 763-764.

Boldrin M. e Levine (2002), 'The Case Against Intellectual Property', American Economic Review, 92, 209-212.

Choi J.P. (1998), 'Brand Extension and Informational Leverage’, Review of Economic Studies, 65, 655-669.

Coase R. (1960), 'The Problem of Social Cost', Journal of Law and Economics, 3, 1-44.

Dasgupta P. and David P. (1994), 'Towards a New Economics of Science’, Research Policy, 23, 487-532.

David P. (1993), 'Intellectual Property Institutions and the Panda's Thumb.Patents,Copyrights and Trade Secrets in Economic Theory and History' in Wallerstein M. B., Mogee M. E., and Schoen R. A. (eds.), Global Dimensions of Intellectual Property Rights in Science and Technology, National Academy Press, Washington DC. 
David P.A. (2000), 'The Digital Technology Boomerang: New Intellectual Property Rights Threaten “Open Science” ', World Bank Conference Volume (forthcoming).

De Vany, A.S. and W.D. Walls (1999), 'Uncertainty in the Movie Industry: Does Star Power Reduce the Terror of the Box Office?', Journal of Cultural Econmics, 23, 285-318.

Drahos, P. (1996), A Philosophy of Intellectual Property, Dartmouth: Aldershot

Evans D.S. and R. Schmalensee (2001), 'Some Economic Aspects of Antitrust

Analysis in Dynamically Competitive Industries’, NBER Working Paper, nº 8268.

Fawcett J.J. and Torremans P. (2001), Intellectual Property and Private International Law, Oxford University Press.

Friedman D.D. (1998), 'Trade Secrets', in Newman P. (ed), The New Palgrave Dictionary of Economics and the Law, Macmillan, London.

Friedman D.D., Landes W.M. and Posner R.A. (1991), 'Some Economics of Trade Secret Law', The Journal of Economic Perspectives, 5, 61-72.

Gilbert R.J. and D. Newbery (1982), 'Preemptive Patenting and the Persistence of Monopoly', American Economic Review, 72, 514-526.

Goldstein P. (1994), Copyright's Highway, New York: Hill and Wang

Gordon W. J. (2003), 'Intellectual Property', in Can P. and Tushnet M. (eds), The Oxfrod Handbook of Legal Studies, Oxfrod University Press.

Gordon W. J. (2002), 'Excuse and Justification in the Law of Fair Use: Commodification and Market Perspectives', in Elkin-Koren N. and Netanel N.W. (eds), The Commodification of Information, Kluwer, The Hague.

Gordon W. J. And Bone R.G. (1999), 'Copyright', in Bouckaert B. and De Gest. G. (eds), Enciclopedia of Law and Economics, Elgar, Cheltenham-Northampton.

Hansmann H. and Santilli M. (1997), 'Authors' and Artists' Moral Rights: A Comparative Legal and Economic Analysis', Journal of Legal Studies, 26, 95-143.

Hardin G. (1968), ‘The Tragedy of Commons', Science, 162, 1243-1248.

Heller M. (1998), 'The Tragedy of AntiCommons: Property in the Transition from Marx to Market', Harvard Law Review, 111, 621-688.

Hirshleifer J. (1971), 'The Private and Social Value of Information and the Reward to Inventive Activity’, American Economic Review, 61, 561-574.

Jha R. (1998), Modern Public Economics, Routledge, London.

Kitch E.W. (1977), 'The Nature and Function of the Patent System', Journal of Law and Economics, 20, 265-290.

Landes W.M. and Posner R.A. (1987), 'Trademark Law: An Economic Perspective', Journal of Law and Economis, 30, 265-309.

Lerner J. and Tirole J. (2001), 'The Open Source Movement: Key Research Questions', European Economic Review, 45, 819-826.

Lessig L. (2001), The Future of Ideas, Random House, New York.

Locke J. (1690), Second Treatise on Government, downloaded at URL: http://www.ilt.columbia.edu/academic/digitexts/locke/second/locke2nd.txt

Marvasti A. (2000), 'Motion Picture Industry: Economies of Scale and Trade', International Journal of the Economics of Business, 7, 99-114. 
Menell P. (1999), 'Intellectual Property: General Theories', in Bouckaert B. and De Gest G. (eds), Enciclopedia of Law and Economics, Elgar, Cheltenham-Northampton.

Merges R. (1999) 'As Many as Six Impossible Patents Before Breakfast: Property Rights for Business Concepts and Patent System Reform’, Berkeley Law Technology Journal 14, 577615.

Metaxas-Maranghidis G. (ed, 1995), Intellectual Property Laws of Europe,Wiley, Chichester.

OECD (1998), Competition Policy and Intellectual Property Rights, OECD, DAFFE/CLP(98)18.

Oz S. (1995), Industrial Organization, MIT Press, Cambridge Mass.

Pepall L. M. and Richards D. J. (2002), 'The Simple Economics of Brand Stretching', Journal of Business, 75, 535-552.

Romer P. (1990), 'Endogenous Technological Change', Journal of Political Economy, 98, 71102.

Ryan M.P.(1998), Knowledge Diplomacy: Global Competition and the Politics of Intellectual Property, Brookings Institutions Press, Washington D.C.

Ramello G.B. (2003a), 'Copyright and Antitrust Issues', in Gordon W. E Watt R. (eds), The Economics of Copyright: Developments in Research and Analysis, Elgar, CheltenhamNorthampton.

Ramello G.B. (2003b), 'Private appropriability and Knowledge Sharing: Contradiction or Convergence ? The Opposite Tragedy of Creative Commons', mimeo.. in Takeyama L., Gordon W. and Towse R. (eds), Developments in the Economics of Copyright: Research and Analysis, Cheltenham, UK-Northampton, MA, USA, Edward Elgar

Ramello G.B. (2001), 'Napster et la musique en ligne. Le mythe du vase de Pandore se répèterait-il ?’, Réseaux, 19, 131-154.

Rushton M. (1998), 'The Moral Rights of Artists: Droit Moral ou Droit Pécuniaire’, Journal of Clultural Economics, 22, 1, 15-32.

Shapiro C. (2000), 'Competition Policy in the Information Age', Foundations of Competition Policy, Routledge, London

Samuelson P. (2000), 'Privacy as Intellectual Property', Stanford Law Review, 52, 1125-1169.

Sappington D.E.M. and Wernerfelt B. (1985), 'To Brand or Not to Brand ? A Theoretical Empirical Question, Journal of Business, 58, 279-283.

Schmalensee R. (1978), 'Entry Deterrence in the Ready-to-eat Breakfast Cereal Industry', Bell Journal of Economics, 9, 305-327.

Schmalensee R. (2000), 'Antitrust Issues in Schumpeterian Industries', American Economic Review, 90, 192-196.

Schumpeter, J. (1943), Capitalism, Socialism and Democracy, Unwin University:London.

Scotchmer S. (1998), 'Incentives to Innovate', in Newman P. (ed.), The New Palgrave Dictionary of Economics and the Law, Macmillan, London.

Scotchmer S. (1991), 'Standing on the Shoulders of Giants: Cumulative Research and the Patent Law', Journal of Economic Perspective, 5, 29-41.

Shapiro C. (2000), 'Competition Policy in the Information Age', Foundations of Competition Policy, Routledge, London 
Silva F. and Ramello G. (2000), 'Sound Recording Market: the Ambiguous Case of Copyright and Piracy’, Industrial and Corporate Change, 9, 415-442.

Solow R. (1957), 'Technical Change and The Aggregate Production Function', Review of Economics and Statistics, 39, 312-320.

Special Issue TRIPS (1998), Journal of International Economic Law, 1, 4.

Strowel A. (1993), Droit d'auteur et copyright, Bruylant, Bruxelles e L.G.D.J., Paris.

Tadelis S. (1999), 'What's in a Name ? Reputation as a Tradable Asset', American Economic Review, 89, 548-563.

Watt R. (2000), Copyright and Economic Theory: Friends or Foes ?, Elgar, CheltenhamNorthampton.

Williamson O.E. (1977), 'Predatory Pricing. A Strategic and Welfare Analysis', Yale Law Journal, 87, 284-340.

Willison D.J. and MacLeod S.M. (2002), 'Patenting of Genetic Material: Ar the Benefits to Society Being Realized ?’, Canadian Medical Association Journal, 167, 259-262.

Zeytlin D. (2003), 'Gift economies in the development of open source software: anthropological reflections’, Research Policy, 32, 1287-1291. 


\section{Notes}

* Paper accepted for publication in Backhaus J.(forthcoming 2005), Elgar Companion to Law and Economics, 2nd Edition, Edward Elgar, Cheltenham-Northampton

${ }^{1}$ We set aside, for the time being, the questions raised by certain authors as to the effective exclusivity of trade secrets, which shall be discussed subsequently, section 3.

${ }^{2}$ For a general overview see Hardin (1968), Besen and Raskind (1991), David (1993), Besen (1998), Menell (1999) and Gordon (2003). On the possibility of alternative solutions to the private ownership of knowledge, see Arrow (1962).

${ }^{3}$ For example, on intellectual property in Chinese culture, see Alford (1995). Again, on the problem of extending the Western doctrine to other cultures, with particular reference to Australian aboriginal society, see Blakeney (1998).

${ }^{4}$ See supra n. 3.

${ }^{5}$ And necessarily so, because it was only with Smith that economics emerged as a separate discipline in its own right.

${ }^{6}$ On the theory of public goods and the dilemma of appropriability, a good review is given in Jha (1998, ch. 4).

${ }^{7}$ For a historical (and dramatic) exposition of the modern theory of intellectual property rights, see the 'tragedy of the commons' by Hardin (1968). See also supra n. 3.

${ }^{8}$ For a more modern treatment connected with growth models, see Romer (1990).

${ }^{9}$ See, again, Hardin (1968) and recently Heller (1998).

10 For a comparative presentation, see for example Metaxas-Maranghidis (1995) and Fawcett and Torremans (2001).

${ }^{11}$ On this topic see the Special Issue TRIPS (1998) of the Journal of International Economic Law and, in critical key, Ryan (1998).

${ }^{12}$ We avoid here a detailed legal explanation of the rights, referring the reader to the abundant literature available (see for example Bently and Sherman (2001). See also Besen (1998) and Menell (1999) for a presentation focusing on economic analysis, but from a US perspective. Somewhat dated, but still of interest, is the contribution by David (1993).

${ }^{13}$ For a concise but excellent introduction to the economic role of patents see Oz (1995, pp. 244-246). A more extensive discussion is instead provided by Kitch (1977).

${ }^{14}$ For a more in-depth analysis see Gordon and Bone (1999) and Watt (2000).

${ }^{15}$ For example, in the case of databases, protected in Europe subsequent to Directive 96/9/EC, the originality lies exclusively in the organisational format of the data.

16 In general such rights are of an economic character (so-called pecuniary rights) -i.e. right of reproduction, right of distribution, right of public performance, right of public display, right of preparing derivative works--and of a moral character (moral rights)-- right of paternity, right of publication and right of integrity (see for instance Bently and Sherman, 2001). On the--highly uncertain-- role of such rights from a law and economics perspective see Rusthon (1998) and Hansmann and Santilli (1997).

${ }^{17}$ See Ramello (2001).

${ }^{18}$ As a rule, economic analysis deals with significantly shorter time horizons, which in no case extend beyond the lifetime of the individuals. One could of course argue that a perfectly informed copyright owner would be able to anticipate the expected profits, and recover them within his lifetime by selling the right in exchange for a remuneration. However perfect information is by no means a feature of these markets where, on the contrary, the utmost uncertainty and asymmetry of information appear to reign (see for example Silva and Ramello, 200; Lessig, 2001; Ramello, 2003a).

${ }^{19}$ For a more in-depth analysis see Friedman, Landes and Posner (1991) and Friedman (1998).

${ }^{20}$ See Samuelson (2000) in particular n. 146 for a detailed discussion of the various positions taken in the debate on this point.

${ }^{21}$ The different owners of the same trade secret must by definition be few in number and unaware of the fact; otherwise the protected information would effectively be disclosed, and hence not a valid subjectmatter for trade secret.

${ }^{22}$ In fact, in the case of multiple paternity the patent is attributed in the US to the first who invents and in the EU to the first who registers. See Bently and Sherman (2001). 
23 The differentiation strategies are in fact pursued by economic actors in order to secure a certain amount of market power. For an introduction to the topic see for example Oz (1995, ch. 7). For an application to the case of trademarks see Sappington and Wernerfelt (1985).

${ }^{24}$ With a few exceptions that only cast doubt on the efficiency of the market--but not on its underlying structure, as in the case of excess innovation (see the historic contribution by Hirshleifer, 1971).

${ }^{25}$ For the copyright industries, see for example Marvasti (2000) for the film industry, Silva and Ramello (2000) for the recording industry, and Armstrong (1999) for pay-TV. In general see OECD (1998).

${ }^{26}$ The equating of intellectual property with market power is certainly not automatic, as has been affirmed by the European Court of Justice (Deutche Gramophon GmbH v. Metro-SB-Grossmrkte GmbH, 78/80, June 8, 1971, ECR 487) and by the US US FTC and DOJ (1995), Antitrust Guidelines for the Licensing of intellectual property.

${ }^{27}$ The causal relation with interchangeability is still accepted in the US Guidelines (sect 2.2) and in the European legislation see supra n. 27.

${ }^{28}$ See again Ramello (2003a, p. 123).

${ }^{29} 110$ F. Supp. 295, D. Mass, 1953, aff'd per curiam, 347 US 251, 1954.

30 Although the first case in which a conflict between exclusive intellectual property rights arose was United Sates v. Paramount Pictures Inc., 334 U.S. 131 (1948).

${ }^{31}$ COMP D3/38.044. This debate was launched by the "Magil" case (Radio Telefis Eireann (RTE) $v$. Commission of the European Communities (C-241/91 P e C-242/91P, April 6, 1995)

32 "Microsoft argues that the licence restrictions are legally justified because, in imposing them, Microsoft is simply $<<$ exercising its rights as the holder of valid copyrights $>>$ Appellant's Opening Br. at 102 [...] The company claims an absolute and unfettered right to use its intellectual property as it wishes $:<<$ [I]f intellectual property rights have been lawfully acquired, $>>$, it says, then $<<$ their subsequent exercise cannot give rise to antitrust liability. $>>$ Appellant's Opening Br. at 105” USA v Microsoft Corp, U.S. DC Court of Appeals, N. 00-5212 consolidated with 00-5213.

${ }^{33}$ A\&M Records, Inc. v. Napster, Inc., 114 F. Supp. 2d 896 (N.D. Cal. 2000); A\&M Records, Inc. v. Napster, Inc., US Court of Appeals ( $9^{\text {th }}$ Circ., 2001).

${ }^{34}$ See for example Ramello (2001).

${ }^{35}$ Lessig (2001, p. XVI) explicitly upholds the thesis of "limiting the control that legal structures such as copyright give to the industries of yesterday to ensure that they can't use the law to constrain the creation of tomorrow".

${ }^{36}$ An OECD report (1998, p. 1997 states that "IPR protection in some sectors (notably biotechnology) and countries may be so broad that it actually inhibits innovation". 